\title{
Integrasi Kecerdasan Holistik RASULULLAH SAW Untuk Generasi Muda Berkarakter di Pendidikan Era Industri 4.0
}

\author{
Fitrotin Jamilah, MHI. (fitrotinjamilah@gmail.com) Dosen Institut \\ Pesantren Abdul Chalim Mojokerto)
}

Siti Farida (faridaisme@gmail.com) Dosen Institut Agama Islam

Nazhatut Thullab Sampang

Ahmad Khotib (ahmadkhotib216@gmail.com)

Joni (jonibaco@gmail.com)

\begin{abstract}
ABSTRAK
Integrasi adalah penggabungan suatu hal agar menjadi satu kesatuan yang utuh dalam satu tujuan. Pada Globalisasi saat ini, pengembangan teknologi dan era revolusi industry 4.0, sebuah era baru yang menekankan pada pola digital economy,artificial intelligence (kecerdasan buatan), big data, robotic. Dimana era 4.0 merupakan fenomena disruptive innovation. Istilah disruptive innovation dicetuskan pertama kali oleh Clayton $\mathrm{M}$. Christensen dan Joseph Bower; inovasi yang membantu menciptakan pasar baru yang mengubah konsep pekerjaan, struktur pekerjaan, dan kompetensi yang dibutuhkan dunia pekerjaan. Era revolusi industri 4.0 juga mengubah cara pandang tentang pendidikan. Perubahan yang dilakukan tidak hanya sekedar cara mengajar, tetapi jauh lebih esensial, yakni perubahan cara pandang terhadap konsep pendidikan itu sendiri. Pendidikan karakter bukan hal yang baru di Indonesia. Tokoh-tokoh pendidik Indonesia pra kemerdekaan, seperti Kartini, Ki Hajar Dewantara, Soekarno Hatta, Moh Natsir sudah memulai apa yang dinamakan pendidikan karakter sebagai semangat pembentukan kepribadian dan identitas bangsa sesuai konteks dan situasi yang terjadi saat itu. Membangun dan mencetak karakter merupakan keprihatinan pokok para tokoh tersebut. Mereka menggagas sebuah bangsa yang memiliki sebuah identitas tersendiri. Ide dan gagasan itu mulai dari hasil pengembaraan dan perantauan mental para pemikir dan cendikiawan. Dari ide dan gagasan itu, muncullah semangat karakter kebangsaan yang harus diperjuangkan dengan perjuangan tanpa akhir sehingga muncullah Negara Indonesia saat ini. Ki Hajar Dewantara misalnya, telah mengajarkan pendidikan karakter melalui praktek pendidikan yang mengusung kompetensi alam murid, bukan dengan perintah paksaan, tetapi dengan tuntunan. Cara mendidik seperti ini lebih dikenal dengan pendekatan among, yang lebih menyentuh pada tataran etika dan perilaku yang tidak terlepas dengan karakter seseorang. Membangun karakter dan watak bangsa melalui pendidikan, mutlak dibutuhkan. Mulai diri sendiri, lingkungan rumah, sekolah, dan masyarakat dengan meneladani para tokoh tersebut.
\end{abstract}

Kata kunci : Industri 4.0, Integrasi, Karakter, Pendidikan. 


\section{BAB I}

\section{PENDAHULUAN}

\section{A. Latar Belakang}

Remaja merupakan generasi penerus sebuah bangsa, kader bangsa, kader masyarakat dan kader keluarga. Remaja selalu diidentifikasi dengan perubahan betapa tidak, peran remaja dalam membangun bangsa ini, peran remaja dalam menegakkan keadilan, peran remaja yang menolak kekuasaan.

Pada dasarnya remaja dituntut aktif dalam kegiatankegiatan masyarakat, sosialisasi dengan warga sekitar. Kehadiran remaja sangat dinantikan untuk menyokong perubahan dan pembaharuan bagi masyarakat dan negara. Aksi reformasi disemua bidang adalah agenda remaja kearah masyarakat madani. Reformasi tidak mungkin dilakukan oleh orang tua dan anak-anak.

Bimbingan dan arahan terhadap remaja sangat diperlukan sebagai upaya agar remaja dapat memiliki kemandirian untuk bertanggung jawab atas pekerjaannya sendiri. Kemampuan kemandirian seperti ini tidak hanya menyangkut aspek akademis, tetapi juga menyangkut aspek perkembangan pribadi, sosial, kematangan intelektual, dan sistem nilai.

Pencapaian kemandirian bagi remaja merupakan sesuatu hal yang tidak mudah. Sebab pada masa remaja terjadi pergerakan perkembangan psikososial dari arah lingkungan keluarga menuju lingkungan luar keluarga. Mereka berusaha 
melakukan pelepasan-pelepasan atas keterikatan yang selama ini dialami pada masa kanak-kanak. Dimana segala yang diatur dan ditentukan oleh orang tua, pemutusan ikatan yang telah berkembang dan dinikmati dengan penuh rasa nyaman selama masa kanak-kanak seringkali menimbulkan reaksi yang sulit di pahami bagi kedua belah pihak bagi remaja maupun orang tua.

Menghadapi tuntutan kemajuan zaman sekarang ini, maka remaja berbakat sebagai pribadi maupun sebagai anggota masyarakat dituntut untuk lebih mandiri dan kreatif dalam mengembangkan kemampuanya. Anak berbakat memiliki kemadirian yang tinggi dan dapat mencapai apa yang dicita-citakanya.

Disisi lain, sebelum menjemput sebuah kebutuhan bangsa Indonesia menjadi lebih maju, sesuai pesan Presiden RI “Pemimpin pendidikan negeri maupun swasta tingkat sekolah dasar sampai perguruan Tinggi wajib mendukung inovasi untuk menghadapi perubahan global dan memenuhi kebutuhan sumber daya manusia Indonesia yang kreatif, Inovatif, dan Kompetitif" (Joko Widodo, 2017). Dimana segala sesuatunya akan tercapai apabila akar sebuah permasalahan pada generasi muda telah di tangani yaitu masalah karakter, dimana terdapat suatu tahap penyempurnaan sikap dan karakter yang tampaknya menjadi kekhawatiran semua elemen masyarakat. Apakah telah terjadi ketidaksingkronan antara tujuan pembentukan sebuah karakter remaja yang baik dengan pola penerapan pendidikan di Indonesia.

Berbagai fenomena timbul di kurun waktu belakangan ini mengenai sikap, moral dan karakter bangsa Indonesia yang menjadi keprihatinan para masyarakat indonesia baik kalangan bawah, kalangan menegah, dan kalangan atas negeri ini, mengenai pelajar maupun pelaku pendidikan. Tidak lama ini 
tepatnya pada tanggal 02 Februari 2018 masyarakat digegerkan oleh kasus Guru Budi. Ahmad Budi Cahyono merupakan salah satu guru yang mengajar di SMAN 1 Torjun Sampang, Madura, Jawa Timur. Malang nasib tak dapat di tolak guru Budi menemui ajalnya usai beliau dianiaya oleh muridnya sendiri. Dari berbagai keterangan Guru Budi merupakan sosok yang baik, sedangkan sang murid yang diketahui bernama $\mathrm{MH}$ merupakan murid yang terkenal badung dan banyak mendapat catatan merah dari guru BK (Bimbingan Konseling). Penganiayaan terjadi saat guru Budi mengajar mata pelajaran melukis, disaat pelajaran berlangsung $\mathrm{MH}$ mengacuhkan guru Budi, bahkan dia mengganggu teman-temannya yang lain, sebab itulah guru Budi pun mengoleskan cat ke pipinya, tak terima dengan perlakuan tersebut $\mathrm{MH}$ langsung mencekik guru Budi. Hingga akhirnya dilerai oleh murid yang lain. ${ }^{1}$

Dengan kasus hampir sama, di tempat yang lain tepatnya pada tanggal 19 April 2018 di daerah Purwekerto, Jawa Tengah. Seorang guru menjadi tersangka perilaku kekerasan terhadap muridnya. Dalam video yang beredar di media tampak sang guru menampar beberapa muridnya. Usut punya usut penyebabnya adalah karena murid yang keterlaluan juga, mereka telat masuk ke dalam kelas karena pergi sarapan tanpa izin terlebih dahulu. ${ }^{2}$

Berbagai permasalahan guru dan murid yang terjadi di Indonesia. Hal ini menunjukkan merosotnya moralitas bangsa. Tak ada rasa hormat seorang murid terhadap gurunya, sehingga semakin memburuklah benih-benih penerus bangsa. Oleh karena itu, solusi yang dapat di terapkan adalah dengan

\footnotetext{
${ }^{1}$ https://googleweblight.com/i?u=regional.compas.com/read/ 2018/02/03/10041991/penganiayaan-guru-oleh-siswa-disamping-beginikronologinya\&h I=id-ID

2 https://m.detik.com/news/jawatengah/3981262/guru-yang-tamparmuridnya-dipurwokerto-dipolisikan-ortu- korban
} 
memperbaiki sistem pendidik karakter bangsa pada tahap yang telah memasuki era revolusi Industri 4.0 yaitu dengan mengambil contoh etika penerapan sikap tauladan akhlak Rasulullah SAW untuk generasi muda sekarang dan di Integrasikan dengan perkembangan teknologi di era industri 4.0 agar dapat membangkitkan semangat para generasi muda demi tercapainya pendidikan berkarakter dalam membangun Indonesia. Atas dasar itu penulis memberikan gagasan yaitu "The Integration Of Holistic Intelligence Prophet For Young Generation Character In Industrial Era Education 4.0" (Integrasi Kecerdasan Holistik Rasulullah SAW Untuk Generasi Muda Berkarakter di Pendidikan Era Industri 4.0)

\section{BATASAN MASALAH}

Berdasarkan latar Belakang yang telah penulis paparkan di atas, penulis merumuskan beberapa identifikasi masalah sebagai berikut :

1. Bagaimanakah Pelaksanaan Tujuan Pendidikan Nasional

2. Bagaimanakah Integrasi Kecerdasan Holistik Rasullah SAW Untuk Generasi Muda Berkarakter Di Pendidikan Era Industri 4.0 ?

3. Apa Sajakah Tahap-tahap Perkembangan Pendidikan Revolusi Indusri era4.0?

\section{Tujuan Penulisan}

Adapun untuk tujuan penulisan yang telah dirumuskan penulis adalah sebagai beriku:

1. Untuk Mengkaji Pelaksanaan Tujuan Pendidikan Nasional.

2. Untuk Mengkaji Integrasi Kecerdasan Holistic Rasulullah SAW Untuk Generasi Muda Berkarakter Di Pendidikan Era Industri 4.0. 
3. Untuk Mengkaji Tahap-Tahap Perkembangan Pendidikan Revolusi Industri.era 4.0. 


\section{A. Batasan Konsep}

Berdasarkan latar belakang di atas ada beberapa referensi yang menjadi rujukan untuk mendukung pembuatan penulisan, diantaranya ialah : (1)Menganalisa dari sudut pandang tujuan pendidikan nasional. Perubahan Undang Undang Dasar Negara Republik Indonesia Tahun 1945 mengenai tujuan pendidikan nasional tercantum dalam pasal 31 ayat (3) Dengan rumusan perubahanya "pemerintah mengusahakan dan menyelenggarakan satu sistem pendidikan nasional, yang meningkatkan keimanan dan ketakwaan serta akhlak mulia dalam mencerdaskan kehidupan bangsa, yang diatur dengan undang-undang", ketentuan ini mengakomodasi nilai-nilai dan pandangan hidup bangsa Indonesia sebagai bangsa yang religius dengan memasukkan rumusan kata meningkatkan keimanan dan ketakwaan serta akhlak mulia sementara tujuan sistem pendidikan nasional ialah untuk mencerdaskan kehidupan bangsa. ${ }^{3}$ (2) Tahap-tahap Revolusi Industri. Tahun 1800an merupakan Industri 1.0 dengan konteks penemuan mesin uap mendorong munculnya kapal uap, kereta api dan sebagainya, Tahun 1900an merupakan industri 2.0 dengan konteks penemuan listrik dan assembly line yang meningkatkan produksi barang, Tahun 2000an sampai sekarang merupakan Industri 3.0 dengan konteks inovasi teknologi komersialisasi personal computer dan Industri 4.0 dengan konteks Revolusi Industri ke-4 mengenai kegiatan manufaktur terintegrasi melalui penggunaan teknologi wirelles dan big data secara massif. ${ }^{4}$ (3) kecerdasan holistik (Intelektual, Emosional,

\footnotetext{
${ }^{3}$ Sekretariat Jendral MPR RI. 2012. Panduan Pemasyarakatan yang memuat tentang materi Undang-Undang Dasar Negara Republik Indonesia Tahun 1945 sesuai dengan urutan Bab, Pasal, dan Ayat serta Ketetapan dan Keputusan MPR,Hal. 191-192

${ }^{4}$ Haris, Abd. 2018. Tantangan, Peluang di Era 4.0. Presentasi disajikan dalam Seminar Nasional Upaya Menyikapi Polemik Sarjana Pendidikan Dasar, Jurusan PGMI UNISLA, Lamongan, 5 Mei.
} 
Spritual dan Kinestetis) ini terlahir dari penawaran sebuah gerakan yang di berikan Nabi Muhammad SAW. Pertama, belajar seumur hidup. Seluruh gerakan pembaharuan di seluruh dunia ini selalu dimulai oleh kalangan terpelajar, orangorang terpelajar ialah mereka yang telah melalui proses belajar dan terus belajar dan tidak akan berhenti belajar hingga ajal menjemputnya. Kedua, hijrah. Pindahnya seseorang atau masyarakat dari kondisi yang buruk menuju kondisi yang lebih baik dalam konteks seutuhnya, konsep hijrah Nabi SAW yang berhubungan dengan pendidikan karakter ialah konsep perubahan ke arah kebaikan dan perbaikan dalam makna yang sebenarnya. Ketiga, muhasabah atau instrospeksi diri. ialah mekanisme evaluasi internal yang sangat luar biasa, yang bisa dilakukan kapan saja dan dimana saja. Karena dalam muhasabah ini yang menjadi terdakwa ialah hati, yang menjadi jaksa ialah hati, serta yang menjadi hakimnya ialah hati. ${ }^{5}$

\section{B. Landasan Teori}

Secara umum terdapat 3 masalah mendasar yang di hadapi generasi muda Indonesia : (1) Tidak adanya sinergi antara tujuan pendidikan nasional dengan implementasi pada pendidikan karakter di era industri 4.0. (2) Menjemput kebutuhan bangsa dengan menyikapi baik dan cerdas revolusi pendidikan di era industri 4.0. (3) Integrasi kecerdasan holistik Rasulullah SAW dengan tujuan pendidikan nasional dalam revolusi pendidikan di era industri 4.0

Dengan demikian, beberapa hal uraian tujuan penulisan adalah: (1) Menganalisa bagaimana permasalahan pendidikan karakter bangsa untuk generasi muda ditinjau dari tujuan pendidikan nasional. (2) Memberikan gambaran bagaimana polemik yang terjadi pada pendidikan jika tidak berlandaskan

\footnotetext{
${ }^{5}$ Mahbubi, M. Pendidikan Karakter. Yogyakarta: Pustaka IImu, 2012, Hal. 65-
} 
karakter yang baik untuk menyikapi revolusi pendidikan era industri 4.0. (3) Memberikan solusi dengan Mengintegrasikan kecerdasan holistik Rasulullah SAW dengan tujuan pendidikan nasional untuk menyikapi perkembangan revolusi pendidikan era industri 4.0.

\section{- Merosotnya Karakter Anak Bangsa Dalam Menyikapi Perkembangan Rovolusi Pendidikan Era Industri 4.0}

Tujuan pendidikan nasional indonesia ialah untuk mencerdasakan kehidupan bangsa, dengan menanamkan nilainilai dan pandangan hidup bangsa Indonesia sebagai bangsa yang religius dengan rumusan kata meningkatkan keimanan dan ketakwaan serta akhlak yang mulia. Namun, pada praktik lapangannya banyak remaja, pemuda-pemudi saat ini tergambarkan sangat bobrok akhlak yang mereka lakukan. Tidak ada lagi nilai kesopanan dan menghormati terhadap guru yang telah mendidik mereka, terlebih orang tua pun di anggap seperti teman tanpa adanya keseganan dengan etika yang baik. Akan hal ini dapat di simpulkan hilangnya nilai reglius dalam diri generasi bangsa sehingga dapat dipahami sulitnya menciptakan generasi yang cerdas dan mempunyai intelektual yang baik.

Persaingan global tidak dapat kita hindari, namun Indonesia masih pada tahap pembenahan karakter dimana negara lain sudah menyikapi perkembangan teknologi dengan baik, menciptakan sesuatu yang baru untuk negara mereka. Pastilah kita akan tertinggal dikarenakan permasalahan majemuk rakyat Indonesia.

Menristekdikti sebagai entry point saat paparan kebijakan Nasional Pendidikan Tinggi Menghadapi Revolusi Industri 4.0 bulan Januari tahun ini. Pernyataan yang sangat tepat. Mengingat ketenagakerjaan Indonesia per Agustus 2017, 
berdasarkan data BPS sebanyak 121, 02 juta orang penduduk bekerja dan masih terdapat 7,04 juta orang menganggur. ${ }^{6}$

Tahap Globalisasi, perkembangan teknologi dan saat ini memasuki era revolusi industri 4.0. sebuah era baru yang menekankan pada pola digital economy, artifical intelligence (kecerdasan buatan), big data, robotic. Dimana era 4.0 merupakan fenomena disruptive innovation. Istilah disruptive innovation dicetuskan pertama kali oleh Clayton M, Christensen dan Joseph Bower; inovasi yang membantu menciptakan pasar baru yang mengubah konsep pekerjaan, struktur pekerjaan, dan kompetensi yang dibutuhkan dunia pekerjaan.

Era revolusi industri 4.0 juga mengubah cara pandang tentang pendidikan. Perubahan yang dilakukan tidak hanya sekedar cara mengajar, tetapi jauh lebih esensial, yakni perubahan cara pandang terhadap konsep pendidikan itu sendiri $^{7}$

${ }^{6}$ Haris, Abd. 2018. Tantangan, Peluang di Era 4.0. Presentasi disajikan dalam Seminar Nasional Upaya Menyikapi Polemik Sarjana Pendidikan Dasar, Jurusan PGMI UNISLA, Lamongan, 5 Mei. https://news.idntimes.com/indonesia/linda/initrategikemendikbud-hadapi-revolusi- industri/ full

${ }^{7}$ Haris, Abd. 2018. Tantangan, Peluang di Era 4.0. Presentasi disajikan dalam Seminar Nasional Upaya Menyikapi Polemik Sarjana Pendidikan Dasar, Jurusan PGMI UNISLA, Lamongan, 5 Mei. Christensen, Clayton M, Dkk. 2015. What Is Disruptive Innovation? . https://hbr.org/2015/12/what-is-disruptive-innovation Christensen, Clayton M. \& Bower, Joseph L. 1995. Disruptive Technologise: Catching the Wave. https://hbr.org/1995/01/disruptive-technologiescatching-the-wave 


\section{BAB III}

\section{METODE PENULISAN}

\section{A. Pendekatan Penulisan}

Penulisan ini dilakukan dengan tujuan untuk mengkaji secara mendalam terkait dengan tujuan Pendidikan nasional yang tercerminkan dalam peraturan Pendidikan nasional, serta konsep Integrasi Kecerdasan Holistic Rasulullah SAW Untuk Generasi Muda Berkarakter Di Pendidikan Era Industri 4.0. Untuk mencapai ujuan tersebut, akan dilakukan penulisan menggunakan metode deskriptip kualitatif dengan pendekatan studi kasus karena lingkup penulisan merupakan permasalahan dalam kehidupan nyata. ${ }^{8}$

\footnotetext{
${ }^{8}$ John W. Creswell, "Penelitian Kualitatif \& Desain Riset", (Yogyakarta :

Pustaka Pelajar, 2014), hal. 135
} 
Penulisan ini menggunakan data primer, yaitu sumber data yang langsung dapat memberikan informasi kepada penulis.9 Data primer didapatkan penulis dari informasi media sosial terhadap problem masalah yang terjadi. Dan digali dalam referensi pada peraturan Pendidikan Nasional. Kemudian di integrasikan dengan buku Pendidikan karakter

\section{BAB IV}

\section{ANALISI DAN HASIL DISKUSI}

\section{A. Pelaksanaan Tujuan Pendidikan Nasional}

Pendidikan karakter bukan hal yang baru di Indonesia. Tokoh-tokoh pendidik Indonesia pra kemerdekaan, seperti Kartini, Ki Hajar Dewantoro, Soekarno Hatta, Moh Natsir sudah memulai apa yang dinamakan pendidikan karakter sebagai semangat pembentukan kepribadian dan identitas bangsa sesuai konteks dan situasi yang terjadi saat itu. 
Membangun dan mencetak karakter bangsa merupakan keprihatinan pokok para tokoh tersebut. Mereka menggagas sebuah bangsa yang memiliki identitas tersendiri. Ide dan gagasan itu mulai dari hasil pengembaraan dan perantauan mental para pemikir dan cendekiawan. Dari ide dan gagasan itu, muncullah semangat karakter kebangsaan yang harus diperjuangkan dengan perjuangan tanpa akhir sehingga muncullah negara Indonesia saat ini.

Ki Hajar Dewantoro misalnya, telah mengajarkan pendidikan karakter melalui praktek pendidikan yang mengusung kompetensi alam murid, bukan dengan perintah, paksaan, tetapi dengan tuntunan. Cara mendidik seperti ini lebih dikenal dengan pendekatan among, yang lebih menyentuh pada tataran etika dan perilaku yang tidak terlepas dengan karakter seseorang. ${ }^{9}$

Membangun karakter dan watak bangsa melalui pendidikan, mutlak dibutuhkan. Mulai diri sendiri, lingkungan rumah, sekolah dan masyarakat dengan meneladani para tokoh tersebut. Ratna Megawangi menilai bahwa pendidikan karakter dan etika di Indonesia saat ini kurang mendapat penekanan dalam sistem pendidikan negara. Pelajaran PKN, Agama atau budi pekerti sekarang selama ini dianggap tidak berhasil. Karena pengajarannya hanya sebatas teori, tanpa adanya refleksi dari nilai-nilai pendidikan tersebut. Dampaknya anak tumbuh menjadi manusia yang tidak memiliki karakter, bahkan dinilai lebih buruk lagi menjadi generasi yang tidak bermoral.

Pemerintah Indonesia dekade awal kemerdekaan sudah mengupayakan adanya pendidikan karakter di sekolah. Hal ini ditegaskan dan dituangkan dalam UU Pendidikan nasional, yaitu

${ }^{9}$ Mahbubi, M. Pendidikan Karakter. Yogyakarta: Pustaka IImu, 2012, Hal. 69 9 Mahbubi, M. Pendidikan Karakter. Yogyakarta: Pustaka IImu, 2012, Hal. 70 
UU No. 4/1950 jo UU No. 12/1954, UU No. 2/1989 hingga UU No. 20/2003.

Pemerintah melalui undang-undang tersebut berupaya agar pendidikan karakter diterapkan secara optimal pada lembaga pendidikan. Namun karakter yang terbentuk justru bertentangan dengan tujuan pendidikan. Dengan demikian diperlukan revitalisasi pendidikan karakter di sekolah. ${ }^{10}$

\section{Integrasi Kecerdasan Holistik Rasulullah SAW Untuk generasi Muda Berkarakter Di Era Pendidikan Revolusi Industri era 4.0}

Pendidikan karakter masa Nabi Muhammad saw terlihat dalam misi di muka bumi untuk menyempurnakan etika mulia. Sebagai hasilnya bahwa orang-orang yang dahulunya dikenal sebagai berkarakter jahiliyah, melalui pendidikan yang diberikan oleh Nabi SAW ketika membangun karakter yang mulia itu, tidak melalui sekolahan. Oleh karena itu, dalam menunaikan tugasnya, beliau tidak menggunakan kurikulum, bahan ajar semacam buku teks, dan termasuk evaluasi yang digunakan guru.

Karakter atau sebutlah etika, rupanya tidak bisa dibentuk oleh sebuah aktivitas dalam belajar dan mengajar di kelas. Karakter memiliki dimensi yang luas dan begitu pula membentuknya. Dalam menunaikan tugasnya membangun etika itu, Nabi mengawalinya dari dirinya sendiri. Sebagai orang orang yang berkarakter, diantaranya sifat yang bisa dipercaya. Nabi dikenal dengan sebutan al-amin, yang artinya ialah orang yang tidak pernah berbohong. Apa saja yang dikatakanya selalu benar. Pribadi Nabi yang mulia seperti itu dikenal secara luas dimasyarakatnya. Pendidikan karakter yang dicontohkan dan ditekankan oleh Nabi Muhammad SAW yaitu jujur, dapat

\footnotetext{
${ }^{10} \mathrm{lbid}$
} 
dipercaya, cerdas dan tabligh. Sifat-sifat tersebutlah yang menjadi karakter khas Nabi Muhammad SAW, selain itu Nabi Muhammad SAW juga menawarkan beberapa pendidikan karakter kepada para sahabat dan masyarakat disekitarnya yang berupa gerakan atau aktivitas yang menjadikan manusia menjadi pribadi yang baru yang lebih baik, lebih unggul, dan lebih mulia.

Pendidikan karakter Erat kaitanya dengan perkembangan pendidikan di era 4.0, megenai seluruh perkembangan teknologi yang masuk ke Indonesia. Namun bangsa Indonesia kewalahan dalam menyikapi masuknya pembaharuan kemajuan yang cepat, di satu sisi jika bangsa dapat memanfaatkan dengan baik perkembangan tersebut akan menjadikan generasi penerus bangsa sangat produktif dengan kekayaan alam yang berlimpah. Gambaran sebaliknya menimpa perkembangan generasi indonesia yaitu kekhawatiran mengenai merosotnya karakter generasi pada saat ini. Seakan Indonesia tidak dapat mengatasi problematika yang terjadi yang akan berdampak negatif terhadap sumber daya manusia yang tercipta melalui pendidikan.

\section{Tahap-tahap Perkembangan Pendidikan Revolusi}

\section{Industri 4.0}

Pendidikan era 4.0 merupakan revolusi perkembangan zaman yang cepat dalam rangka menjemput sebuah kebutuhan bangsa yang maju dengan aspek penekanan terhadap inovation, producing, dan educatoin. Dengan ciri-ciri : (1) Tidak terlalu penting kritik dan aristik. (2) Lebih ke skill ( persiapan konsep dan terjun dalam jurusan). (3) kuliah langsung dalam industri. (4) kerja sama dengan industri.

Dalam bagan revolusi tampak: 


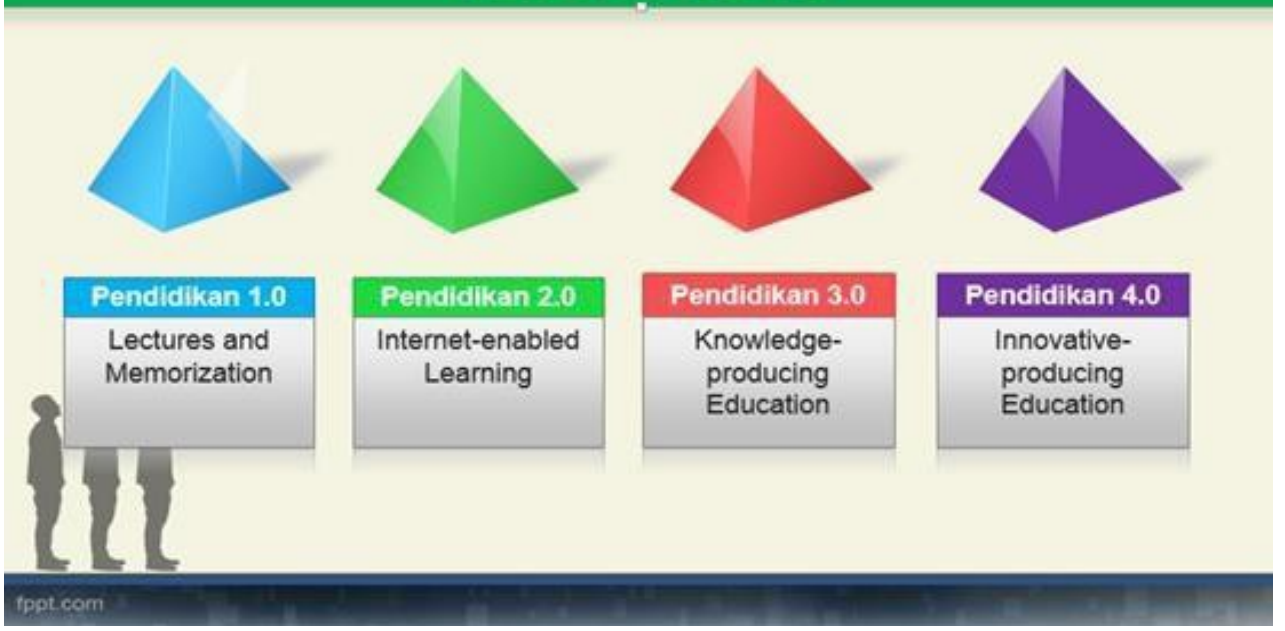

Beberapa langkah-langkah penguatan SDM sarjana pendidikan dasar untuk menyikapi pendidikan era 4.0 ialah: (1) komitmen peningkatan investasi di pengembangan digital skills. (2) Selalu mencoba dan menerapkan prototype teknologi terbaru, Learn by doing. (3) menggali bentuk kolaborasi baru bagi model sertifikasi atau pendidikan dalam ranah peningkatan digital skill. (4) Dilakukanya kolaborasi antara dunia industri, akademisi, dan masyarakat untuk mengidentifikasi permintaan dan ketersediaan skill bagi era digital di masa depan. (5) Menyusun kurikulum pendidikan yang telah memasukkan materi terkait human-digital skills. ${ }^{11}$

${ }^{11}$ Haris, Abd. 2018. Tantangan, Peluang di Era 4.0. Presentasi disajikan dalam Seminar Nasional Upaya Menyikapi Polemik Sarjana Pendidikan Dasar, Jurusan PGMI UNISLA, Lamongan, 5 Mei 


\section{BAB V}

\section{PENUTUP}

\section{A. Kesimpulan}

Berdasarkan pembahasan dari hasil kepenulisan, penulis memberikan beberapa poin penting dalam kesimpulan, diantaranya sebagai berikut :

1. Dalam mengkaji pelaksanaan tujuan Pendidikan nasional terdapat kerangka berpikir yang termaktub dalam Perubahan Undang-Undang Dasar Negara Republik Indonesia Tahun 1945 mengenai tujuan pendidikan nasional tercantum dalam pasal 31 ayat (3) Dengan rumusan perubahanya "pemerintah mengusahakan dan menyelenggarakan satu sistem pendidikan nasional, yang meningkatkan keimanan dan ketakwaan serta akhlak mulia dalam mencerdaskan kehidupan bangsa, yang diatur dengan undang-undang", ketentuan ini mengakomodasi nilai-nilai dan pandangan hidup bangsa Indonesia sebagai bangsa yang religius dengan memasukkan rumusan kata meningkatkan keimanan 
dan ketakwaan serta akhlak mulia sementara tujuan sistem pendidikan nasional ialah untuk mencerdaskan kehidupan bangsa.

2. Integrasi kecerdasan holistic Rasulullah SAW untuk generasi Muda Berkarakter di Pendidikan Era Industri 4.0, merupakan kecerdasan holistik (Intelektual, Emosional, Spritual dan Kinestetis) ini terlahir dari penawaran sebuah gerakan yang di berikan Nabi Muhammad SAW. Pertama, belajar seumur hidup. Seluruh gerakan pembaharuan di seluruh dunia ini selalu dimulai oleh kalangan terpelajar, orangorang terpelajar ialah mereka yang telah melalui proses belajar dan terus belajar dan tidak akan berhenti belajar hingga ajal menjemputnya. Kedua, hijrah. Pindahnya seseorang atau masyarakat dari kondisi yang buruk menuju kondisi yang lebih baik dalam konteks seutuhnya, konsep hijrah Nabi SAW yang berhubungan dengan pendidikan karakter ialah konsep perubahan ke arah kebaikan dan perbaikan dalam makna yang sebenarnya. Ketiga, muhasabah atau instrospeksi diri. ialah mekanisme evaluasi internal yang sangat luar biasa, yang bisa dilakukan kapan saja dan dimana saja. Karena dalam muhasabah ini yang menjadi terdakwa ialah hati, yang menjadi jaksa ialah hati, serta yang menjadi hakimnya ialah hati

3. Tahap-tahap perkembangan Pendidikan Revolusi Industri 4.0 ialah tahap-tahap revolusi industry yang berjalan diantara Tahun 1800an merupakan Industri 1.0 dengan konteks penemuan mesin uap mendorong munculnya kapal uap, kereta api dan sebagainya, Tahun 1900an merupakan industri 2.0 dengan konteks penemuan listrik dan assembly line yang meningkatkan produksi barang, Tahun 2000an sampai sekarang merupakan Industri 3.0 dengan konteks inovasi teknologi komersialisasi personal computer dan 
Industri 4.0 dengan konteks Revolusi Industri ke-4 mengenai kegiatan manufaktur terintegrasi melalui penggunaan teknologi wirelles dan big data secara masif

Dengan demikian The Integration Of Holistic Intelligence Prophet For Young Generation Character In Industrial Era Education 4.0 mampu menjadi sebuah referensi para pendidik, dengan menggabungkan sikap yang tercermin dari Rasulullah SAW yang berupa sebuah gerakan yang akan membantu dalam menciptakan generasi yang memiliki kecerdasan menyeluruh mengenai kecerdasan intelektual, emosional, piritual dan kinestetis. Sehingga suatu generasi bangsa akan tercipta dengan berlandasakan nilai-nilai sikap yang di cerminkan Rasulullah SAW. Sehingga akan menciptakan kader bangsa yang produktif sesuai dengan perkembangan era 4.0.

\section{B. Saran}

Demikian pembahasan penulisan karya ilmiah dari kami, mengenai The Integration Of Holistic Intelligence Prophet For Young Generation Character In Industrial Era Education 4.0. penulis menyadari masih banyak kekurangan dari segi penulisan dan pemaparan. Sehingga penulis mengharapkan saran dari para pembaca terkait dengan perkembangan ilmu pengetahuan yang lebih baik. Terutama mengenai kepenulisan ilmiah ini.

\section{DAFTAR PUSTAKA}

Haris, Abd. 2018. Tantangan, Peluang di Era 4.0. Presentasi disajikan dalam Seminar Nasional Upaya Menyikapi Polemik Sarjana Pendidikan Dasar, Jurusan PGMI UNISLA, Lamongan, 5 Mei. 
https://googleweblight.com/i?u=regional.compas.com/read/ 2018/02/03/10041991/penganiayaan-guru-oleh-siswa-disampingbegini-kronologinya\&hl=id-ID

https://m.detik.com/news/jawatengah/3981262/guru-yangtampar-muridnya-dipurwokerto-dipolisikan-ortu-korban 2012

Mahbubi, M. Pendidikan Karakter. Yogyakarta: Pustaka IImu,

Sekretariat Jendral MPR RI. 2012. Panduan Pemasyarakatan yang memuat tentang materi Undang-Undang Dasar Negara RepublSik Indonesia Tahun 1945 sesuai dengan urutan Bab, Pasal, dan Ayat serta Ketetapan dan Keputusan MPR, 